\title{
APPLICATION OF A GEOMETRICAL MODEL FOR YIELD AND ITS COMPONENTS OF SOME COTTON GENOTYPES (G.barbadense L.)

\author{
EL-ADLY, H.H., A.E.M.EISSA AND H.S.KHALEFA
}

Cotton Research Institute, ARC, Giza

(Manuscript received 3 November 2008)

\begin{abstract}
Yield model was developed for selected cotton genotypes (Gossypim barbadense. L). Yield was equated with the volume of rectangular parallelepiped having the following dimensions, bolls per square meter $(X)$, seed per boll $(Y)$ and seed cotton per seed (Z). Axis (Z) was divided into its two fractions, lint per seed (L/S) and weight per seed (SW/S). Meanwhile, lint yield was expressed by rectangular parallelepiped (XYL).Yield components of the selected genotypes were expressed as a percentage of Giza90 over five locations in Middle and Upper Egypt in 2007 season.

The results showed that, bolls per square meter ( $X$ axis) had the greatest influence on yield. Breeder expects that the greatest gain in yield improvement should come from exerting selection pressure on this character. Concurrent selection pressure should also be placed on seeds per boll $(\mathrm{Y})$ and seed cotton per seed $(\mathrm{Z})$. Data were presented to illustrate a use of model to define the component of yield more susceptible to alteration to increase yield.
\end{abstract}

\section{INTRODUCTION}

Breeder in cotton breeding programs aimed at the production of new varieties with high productivity and desirable fiber traits through selected strains which were examined in trial (B) grown in several locations.

Geometric yield model used was to compare the effects of various yield components on cotton yield. The material used in this study included the selected genotypes from Egyptian cotton breeding program at Middle and Upper Egypt in 2007 season. Atta et all (1989) used geometrical yield model and stated that the greatest gain in yield improvement can be reached by exerting selection pressure for more bolls per unit area followed by seed cotton per seed and seed per boll. Abou-Zahra et al (1993) expressed cotton yield and its components in a geometric model in which seed cotton yield was equated with volume of rectangular parallelepiped having the following dimensions $(X),(Y)$ and $(Z)$ equal to bolls per square meter, seed per boll and seed cotton per seed respectively. Axis (Z) was divided into two fractions, lint per seed ( $L$ ) and weight per seed (S).Meanwhile, lint yield was expressed by the rectangular parallelepiped ( $X Y L$ ). They showed that, bolls per square meter ( $X$ axis) had the greatest influence on yield followed by seeds per boll $(Y)$ and seed cotton per seed (Z). 
The objective of this study is to use the geometric yield model proposed by Kerr (1966) and Maner et al. (1971) to compare the effects of various yield components on yield of some genotypes (Gossypium barbadense L.) selected through cotton breeding program in Middle and Upper Egypt.

\section{MATERIALS AND METHODS}

Eighteen breeding lines were used in this study derived from fourteen hybrids, in addition to the two commercial varieties Giza90 and Giza80, were used in this study Table 1.

In 2007 season all genotypes were grown in a randomized complete block design experiment over five locations (Beni suief, El-Fayoum, El-Minia, Assuit and Sohag) with four replications for each experiment. Each plot consisted of eight rows 4 meter long, $60 \mathrm{~cm}$ apart and $20 \mathrm{~cm}$ between hills. The hills were thinned to two plants/ hill. The six central rows of each plot were hand harvested to determine seed cotton yield per plot (in grams). A random sample of 50 bolls, were harvested from the two outer rows to determine boll weight, lint percentage and seed index. After ginning, fiber properties were tested for four replications.

Combined analysis of variance was performed over the five environments to detect the genotypes by environment interaction as described by Snedecor and Cochran (1967).

Yield model proposed by Kerr (1966) and Maner et.al (1971), was applied for ten genotypes which differed significantly from the check variety Giza90 in mean of seed cotton yield (based on the results of combined analysis over the five locations). Seven traits were calculated from the studied traits as follows:

1- Seed cotton yield $\mathrm{g} / \mathrm{m}^{2}\left(\mathrm{SCY} / \mathrm{m}^{2}\right)=$ plot yield $(\mathrm{g}) /$ plot area $\left(\mathrm{m}^{2}\right)$.

2- Bolls numbers per $\mathrm{m}^{2}\left(\mathrm{~B} / \mathrm{m}^{2)}=\left(\mathrm{SCY} / \mathrm{m}^{2}\right) /\right.$ boll weight in $(\mathrm{g})$.

3- Seed per boll $(S / B)=$ boll weight $(100-L \%) /$ seed index.

4- Seed cotton per seed $(\mathrm{SCS})=$ boll weight $/(\mathrm{S} / \mathrm{B})$.

5- Lint per seed $(\mathrm{L} / \mathrm{S})=(\mathrm{SCS}) \times(\mathrm{L} \%)$.

6- Seed weight $/$ seed $(S W / S)=$ seed index $/ 100$.

7- Lint yield in $\mathrm{g} / \mathrm{m}^{2}\left(\mathrm{LY} / \mathrm{m}^{2}\right)=\left(\mathrm{SCY} / \mathrm{m}^{2}\right) \times(\mathrm{L} \%)$.

8- $\quad$ Number of fiber per seed $(F / S)=(L / S) /(M / L) \times(M i c)$.

The seed cotton yield, for each of the seven genotypes along with the check variety Giza90 was equated with the volume of a rectangular parallelepiped having dimensions $x$ for bolls per unit area $\left(B / \mathrm{m}^{2}\right), Y$ for seed per boll $(S / B)$ and $Z$ for seed cotton per seed (SCS). Axis $Z$ was divided into two fractions, lint weight per seed (L) and weight per seed (S). Lint yield is the volume of $X Y L$. 
Table 1. Pedigree of the cotton genotypes used in this study.

\begin{tabular}{|c|c|c|c|}
\hline NO. & Strain & parents & Origin \\
\hline 1 & $\mathrm{H}_{5} 95 / 2005$ & $\mathrm{H}_{4} 57 / 2004$ & {$[\mathrm{G} 83 \times(\mathrm{G} 72 \times \mathrm{Dan})] \times \mathrm{G} 80$} \\
\hline 2 & $\mathrm{H}_{5} 104 / 2005$ & $\mathrm{H}_{4} 73 / 2004$ & {$[\mathrm{G} 83 \times(\mathrm{G} 72 \times \mathrm{Dan}) \times \mathrm{G} 91$} \\
\hline 3 & $\mathrm{H}_{5} 124 / 2005$ & $\mathrm{H}_{4} 81 / 2004$ & {$[\mathrm{G} 83 \times(\mathrm{G} 72 \times$ Dan $)] \times \mathrm{G} 85$} \\
\hline 4 & $\mathrm{H}_{5} 141 / 2005$ & $\mathrm{H}_{4} 109 / 2004$ & [(G83 x G80) x G75] x (G83 x Pima S6) \\
\hline 5 & $\mathrm{H}_{5} 146 / 2005$ & $\mathrm{H}_{4} 117 / 2004$ & {$[(\mathrm{G} 83 \times \mathrm{G} 80) \times \mathrm{G} 75] \times$ Australian } \\
\hline 6 & $\mathrm{H}_{5} 149 / 2005$ & $\mathrm{H}_{4} 124 / 2004$ & G72 x Pima S6 \\
\hline 7 & $\mathrm{H}_{6} 161 / 2005$ & $\mathrm{H}_{5} \quad 129 / 2004$ & {$[\mathrm{G} 83 \times(\mathrm{G} 75 \times 5844)] \times[\mathrm{G} 83 \times(\mathrm{G} 72 \times$ Dan $)]$} \\
\hline 8 & $\mathrm{H}_{6} 162 / 2005$ & & " \\
\hline 9 & $\mathrm{H}_{6} 166 / 2005$ & $H_{5} \quad 145 / 2004$ & \\
\hline 10 & $\mathrm{H}_{6} 173 / 2005$ & $H_{5} \quad 150 / 2004$ & {$[\mathrm{G} 83 \times(\mathrm{G} 75 \times 5844)] \times \mathrm{G} 80$} \\
\hline 11 & $\mathrm{H}_{6} 175 / 2005$ & $\mathrm{H}_{5} 151 / 2004$ & " $"$ \\
\hline 12 & $\mathrm{H}_{6} 188 / 2005$ & $H_{5} \quad 159 / 2004$ & {$[\mathrm{G} 83 \times(\mathrm{G} 75 \times 5844)] \times(\mathrm{G} 80 \times$ Pima S6) } \\
\hline 13 & $\mathrm{H}_{7} 203 / 2005$ & $\mathrm{H}_{6} 171 / 2004$ & $($ G83 x Delt 703) $\times($ G83 x Pima S6) \\
\hline 14 & $\mathrm{H}_{7} 213 / 2005$ & $\mathrm{H}_{6} 196 / 2004$ & G90 x Australian \\
\hline 15 & $\mathrm{H}_{7} 221 / 2005$ & $\mathrm{H}_{6} \quad 204 / 2004$ & G83 Radiator x G90 \\
\hline 16 & $\mathrm{H}_{7} 226 / 2005$ & $\mathrm{H}_{6} \quad 209 / 2004$ & G91 x G90 \\
\hline 17 & $\mathrm{H}_{7} 227 / 2005$ & " " & " $"$ \\
\hline 18 & $\mathrm{H}_{8} 234 / 2005$ & $\mathrm{H}_{7} 213 / 2004$ & G83 x Pima S7 \\
\hline 19 & \multicolumn{2}{|c|}{ Giza90 } & G83 x Dan \\
\hline 20 & \multicolumn{2}{|c|}{ Giza80 } & G66 x G73 \\
\hline
\end{tabular}

\section{RESULTS AND DISCUSSION}

Yield components for Giza90 base model are expressed as 100\% (Fig. 1), with three axes $X\left(B / m^{2}\right), Y(S / B)$ and $Z(S C S)$. The yield box and its components for the line $\mathrm{H}_{5}$ 104/2005 of the hybrid [(Giza83 x (Giza72 x Dandara)] x Giza91 (Fig.2) showed that the yield component of bolls number per square meter $\left(B / m^{2}\right)$ was caused by increase from the base. The value for this axis $(X)$ was only $117 \%$ of the corresponding value for Giza90. Yield of seed cotton and lint yield were $99.2 \%$ and $117 \%$., respectively. Another yield component seed per boll (S/B) axis (Y) and seed cotton per seed (SCS) axis (Z) were $101 \%$ and $100 \%$ respectively, compared with the value base for Giza90. (Table 2 and Fig.2).

The yield box and its components for line $\mathrm{H}_{5}$ 124/2005 of the hybrid [(Giza83 $x$ (Giza72 $x$ Dandara)] x Giza91 (Table 2 and Fig3) indicated that the axis $\times\left(B / \mathrm{m}^{2}\right.$ ) contributed to the significant increase in its seed cotton yield and lint yield $(115 \%)$ as compared to Giza90 and the effects was probablydue to $\mathrm{B} / \mathrm{m}^{2}(117 \%)$.

Yield components model for line $\mathrm{H}_{5}$ 141/2005 of the hybrid [(Giza83 x (Giza72 x Dandara)] $x$ Giza85 indicated that the axis $\times\left(B / \mathrm{m}^{2}\right)$ was responsible for increase in seed and lint cotton yield $107 \%$ and $108 \%$, respectively compared was Giza 90 variety (Table 2 and Fig4)

The yield model and its components for lines $\mathrm{H}_{6}$ 161/2005, $\mathrm{H}_{6}$ 162/2005and $\mathrm{H}_{6}$ 166/2005 of the hybrid [Giza83 (Giza75 x 5844)] x [(Giza83 x (Giza72 x Dandara)] as shown in Fig $(5,6$ and 7$)$ indicated that the bolls number per square meter $\left(B / \mathrm{m}^{2}\right)$ 
axis $X$ was responsible for their higher yielding ability in seed cotton yield (109\%, $119 \%$ and $111 \%$, respectively and lint yield $(111 \%, 121 \%$ and $112 \%$, respectively as compared with the base variety Giza90.

Table 2. Means of yield and yield components of the lines and cultivated varieties grown in B trails at five different locations in 2007 season.

\begin{tabular}{|c|c|c|c|c|c|c|c|c|c|}
\hline No. & $\begin{array}{l}\text { Genotype } \\
\text { Strain }\end{array}$ & Origin & $\mathrm{SCY} / \mathrm{m}^{2}$ & $\mathrm{~B} / \mathrm{m}^{2}$ & S/B & $\mathrm{SC} / \mathrm{S}$ & L/S & SW/S & $\mathrm{LY} / \mathrm{M}^{2}$ \\
\hline 1 & $\begin{array}{c}\mathrm{H}_{5} \\
95 / 2005 \\
\end{array}$ & $\begin{array}{c}{[\mathrm{G} 83 \times(\mathrm{G} 72 \times} \\
\text { Dan)] // G80 }\end{array}$ & 365.59 & 126.22 & 17.93 & 0.266 & 0.066 & 0.103 & 147.50 \\
\hline 2 & $\begin{array}{c}\mathrm{H}_{5} \\
104 / 2005 \\
\end{array}$ & $\begin{array}{c}\text { [G83 x (G72 x } \\
\text { Dan)] // G91 }\end{array}$ & $418.44^{* *}$ & 135.38 & 18.39 & 0.272 & 0.066 & 0.103 & 164.06 \\
\hline 3 & $\begin{array}{c}\mathrm{H}_{5} \\
124 / 2005\end{array}$ & $\begin{array}{c}{[\mathrm{G} 83 \times(\mathrm{G} 72 \times} \\
\text { Dan)] // G85 }\end{array}$ & 408.23 & 134.99 & 17.93 & 0.274 & 0.067 & 0.103 & 160.99 \\
\hline 4 & $\begin{array}{c}\mathrm{H}_{5} \\
141 / 2005\end{array}$ & $\begin{array}{c}(\mathrm{G} 83 \times \mathrm{G} 80) \times \\
\mathrm{G} 75] / /(\mathrm{G} 83 \times \\
\text { Pima S6) }\end{array}$ & 379.10 & 124.11 & 18.27 & 0.271 & 0.067 & 0.100 & 151.44 \\
\hline 5 & $\begin{array}{c}\mathrm{H}_{5} \\
146 / 2005\end{array}$ & $\begin{array}{c}{[(\mathrm{G} 83 \times \mathrm{G} 80) \times} \\
\mathrm{G} 75] / / \\
\text { Australian }\end{array}$ & 378.33 & 125.57 & 18.10 & 0.266 & 0.067 & 0.101 & 150.50 \\
\hline 6 & $\begin{array}{c}\mathrm{H}_{5} \\
149 / 2005 \\
\end{array}$ & G72 // Pima S6 & 336.01 & 108.34 & 18.65 & 0.267 & 0.067 & 0.100 & 133.77 \\
\hline 7 & $\begin{array}{c}\mathrm{H}_{6} \\
161 / 2005\end{array}$ & $\begin{array}{l}{[\mathrm{G} 83 \times(\mathrm{G} 75 \times} \\
5844)] / /[\mathrm{G} 83 \\
\times(\mathrm{G} 72 \times \text { Dan)] }\end{array}$ & $393.02^{* *}$ & 125.58 & 18.88 & 0.266 & 0.067 & 0.101 & 156.21 \\
\hline 8 & $\begin{array}{c}H_{6} \\
162 / 2005 \\
\end{array}$ & $"$ & 422.99 & 138.58 & 18.16 & 0.272 & 0.068 & 0.103 & 168.39 \\
\hline 9 & $\begin{array}{c}\mathrm{H}_{6} \\
166 / 2005 \\
\end{array}$ & $"$ & 393.26 & 131.48 & 17.55 & 0.272 & 0.068 & 0.103 & 156.71 \\
\hline 10 & $\begin{array}{c}H_{6} \\
173 / 2005 \\
\end{array}$ & $\begin{array}{l}{[\mathrm{G} 83 \times(\mathrm{G} 75 \times} \\
5844)] / / \mathrm{G} 80 \\
\end{array}$ & $438.44^{* *}$ & 141.60 & 18.30 & 0.270 & 0.068 & 0.101 & 175.94 \\
\hline 11 & $\begin{array}{c}\mathrm{H}_{6} \\
175 / 2005 \\
\end{array}$ & " & $413.96^{* *}$ & 134.01 & 18.19 & 0.273 & 0.068 & 0.104 & 163.68 \\
\hline 12 & $\begin{array}{c}\mathrm{H}_{6} \\
188 / 2005\end{array}$ & $\begin{array}{c}{[\mathrm{G} 83 \times(\mathrm{G} 75 \times} \\
5844)] / /(\mathrm{G} 80 \\
\text { x Pima S6) }\end{array}$ & 386.01 & 126.28 & 18.46 & 0.267 & 0.067 & 0.102 & 152.75 \\
\hline 13 & $\begin{array}{c}\mathrm{H}_{7} \\
203 / 2005\end{array}$ & $\begin{array}{l}\text { (G83 x Delt } \\
\text { 703) // (G83 x } \\
\text { Pima S6) }\end{array}$ & 376.67 & 125.96 & 18.12 & 0.267 & 0.068 & 0.101 & 150.88 \\
\hline 14 & $\begin{array}{c}\mathrm{H}_{7} \\
213 / 2005\end{array}$ & $\begin{array}{c}\text { G90 // } \\
\text { Australian }\end{array}$ & $401.22^{* *}$ & 134.83 & 17.68 & 0.271 & 0.067 & 0.103 & 156.78 \\
\hline 15 & $\begin{array}{c}\mathrm{H}_{7} \\
221 / 2005\end{array}$ & $\begin{array}{c}\text { G83 Radiator // } \\
\text { G90 }\end{array}$ & 395.28 & 132.05 & 17.56 & 0.272 & 0.067 & 0.104 & 155.39 \\
\hline 16 & $\begin{array}{c}\mathrm{H}_{7} \\
226 / 2005 \\
\end{array}$ & G91 // G90 & $379.46^{* *}$ & 128.15 & 17.68 & 0.270 & 0.067 & 0.104 & 149.30 \\
\hline 17 & $\begin{array}{c}\mathrm{H}_{7} \\
227 / 2005 \\
\end{array}$ & $"$ & 427.85 & 143.54 & 17.90 & 0.264 & 0.066 & 0.101 & 168.71 \\
\hline 18 & $\begin{array}{c}\mathrm{H}_{8} \\
234 / 2005 \\
\end{array}$ & G83 // Pima S7 & $389.69^{* *}$ & 126.48 & 18.13 & 0.269 & 0.068 & 0.103 & 155.03 \\
\hline 19 & Giza90 & G83 // Dan & 354.13 & 115.27 & 18.26 & 0.272 & 0.067 & 0.103 & 139.74 \\
\hline 20 & Giza80 & G66 // G73 & 333.65 & 114.24 & 18.10 & 0.268 & 0.065 & 0.101 & 130.03 \\
\hline
\end{tabular}

$*$, Highly significant at $1 \%$ level of probability. 
The yield models for lines $\mathrm{H}_{6}$ 173/2005 and $\mathrm{H}_{6}$ 175/2005 of the hybrid [(Giza83 $\mathrm{x}$ (Giza75 $x$ 5844)] $x$ Giza80 showed that the bolls per square meter $\left(B / m^{2}\right)$ axis $(X)$ was responsible for their higher yielding ability in seed cotton yield (123\% and $117 \%$ respectively) and lint yield (126\% and $117 \%$ respectively) as compared with the base variety Giza90 (Fig 8 and 9).

Regarding to hybrid [Giza83 (75x5844)] x (Giza80 x Pima S6), line $\mathrm{H}_{6}$ 188/2005 (Fig 10) exceeded significantly the check variety Giza90 in seed cotton yield and lint yield by $109 \%$, these increments caused by increasing bolls number per square meter $\left(\mathrm{B} / \mathrm{m}^{2}\right)$ axis $\mathrm{X}$, which was $110 \%$ (Table 2 and Fig 10 ).

The yield model and its components for line $\mathrm{H}_{7}$ 213/2005 of the hybrid (Giza90 $x$ Australian) (Fig. 11) reiterate the effect of bolls per unit aria on yield, when bolls number per square meter $\left(\mathrm{B} / \mathrm{m}^{2}\right)$ value was $117 \%$, seed cotton and lint yields were $113 \%$ and $112 \%$ compared with Giza90 variety. Another components that also influence in yield was seed per boll (S/B) axis ( $Y$ ) 97\% compared with Giza90 and seed cotton per seed (SCS) axis (Z) which relatively had the same value as Giza 90.

Yield model and its components for the line $\mathrm{H}_{7}$ 221/2005 (Giza83 Radiatored $x$ Giza90) as shown in Table (2) and Fig (12), indicated that boll number per square meter $\left(\mathrm{B} / \mathrm{m}^{2}\right)$ was $115 \%$ and showed an increase in seed cotton yield $(111 \%)$ as compared by the check variety Giza90.

The yield box and its components for lines $\mathrm{H}_{7} 226 / 2005$ and $\mathrm{H}_{7} 227 / 2005$ of the hybrid (Giza91 x Giza90) (Fig.13 and 14) indicated that the bolls number per square meter $\left(\mathrm{B} / \mathrm{m}^{2}\right)$ was responsible for the significant increase in its seed cotton yield by $107 \%$ and $121 \%$, respectively and lint yield by $106 \%$ and $121 \%$, respectively, as compared with the base variety Giza $90 . \mathrm{B} / \mathrm{m}^{2}$ axis $\mathrm{X}$ recorded $111 \%$ and $125 \%$, respectively.

However, the seeds per boll (S/B) axis ( $\mathrm{Y}$ ) and seed cotton per seed (SCS) axis (X) for line $\mathrm{H}_{8} 234 / 2005$ of the hybrid (Giza83 x Pima S7) were lower than that obtained for Giza90 (99\%), its seed cotton yield and lint yield were significantly lower than that of Giza90 (110\% and $111 \%)$, respectively. The main effect was due to $\mathrm{B} / \mathrm{m}^{2}$ (110\%), Table (2) and Figar (15).

Generally the importance of the $(X)$ axis and the influence of the $(Y)$ and $(Z)$ axes, from the standpoint of the contribution mode to yield are evident in this study. We believed that the greatest gain in yield can be obtained by exerting selection pressure for more bolls per unit area ( $X$ axis). Concurrent selection pressure should also be placed on seed per boll ( $Y$ axis) and seed cotton per seed ( $Z$ axis). Therefore, cotton breeder must direct his program to select plants with the highest number of bolls per 
plant, seeds per bolls and seed cotton per seed concomitantly to maintain or to increase lint per seed. These results are in harmony with those obtained

Kerr (1966), Shafshak et al., (1987), Atta et al., (1989) and Abou-Zahra et al., (1993).

The correlation coefficients of lint yield components are shown in Table (2). These data indicate highly significant and significant positive correlation between micronaire value (Mic) with upper half mean length (UHM), lint yield per square meter (LY/M $\left.{ }^{2}\right)$ and number of bolls number per square meter $\left(B / \mathrm{M}^{2}\right)$. On the other hand the micronaire value (Mic) recorded significant negative correlation with number of fiber per seed (F/S) and lint per seed (L/S). Highly significant positive correlation was found between number of fiber per seed $(F / S)$ and lint per seed $(L / S)$, while it was negatively significant correlated with seed per boll $(S / B)$, lint yield per square meter $\left(L Y / M^{2}\right)$ and number of bolls number per square meter $\left(B / M^{2}\right)$. Highly negative significant and significant correlation was found between lint per seed (L/S) and number of bolls number per square meter $\left(B / M^{2}\right)$. Seed per boll $(S / B)$ shows significant negative correlation with lint yield per square meter $\left(L Y / M^{2}\right)$. Highly significant positive correlation was obtained between number of bolls per number square meter $\left(B / M^{2}\right)$ and lint yield per square meter $\left(L Y / M^{2}\right)$ as would be logically expected.

Table 3. Correlation coefficients of lint yield and its components.

\begin{tabular}{|ccccccc|}
\hline & UHM & F/S & L/S & S/B & B/M2 & LY/M2 \\
\hline Mic & $0.358^{* *}$ & $-0.003^{*}$ & $-0.002^{*}$ & 0.219 & $0.310^{*}$ & $0.420^{* *}$ \\
UHM & & 0.014 & 0.016 & 0.151 & -0.078 & 0.032 \\
F/ S & & & $0.981^{* *}$ & $-0.494 * *$ & $-0.078^{*}$ & $-0.153^{* *}$ \\
L/S & & & & $-0.443^{* *}$ & $-0.142 *$ & 0.195 \\
S/B & & & & & -0.086 & $-0.145^{*}$ \\
B/M & & & & & & $0.933^{2} *$ \\
\hline
\end{tabular}




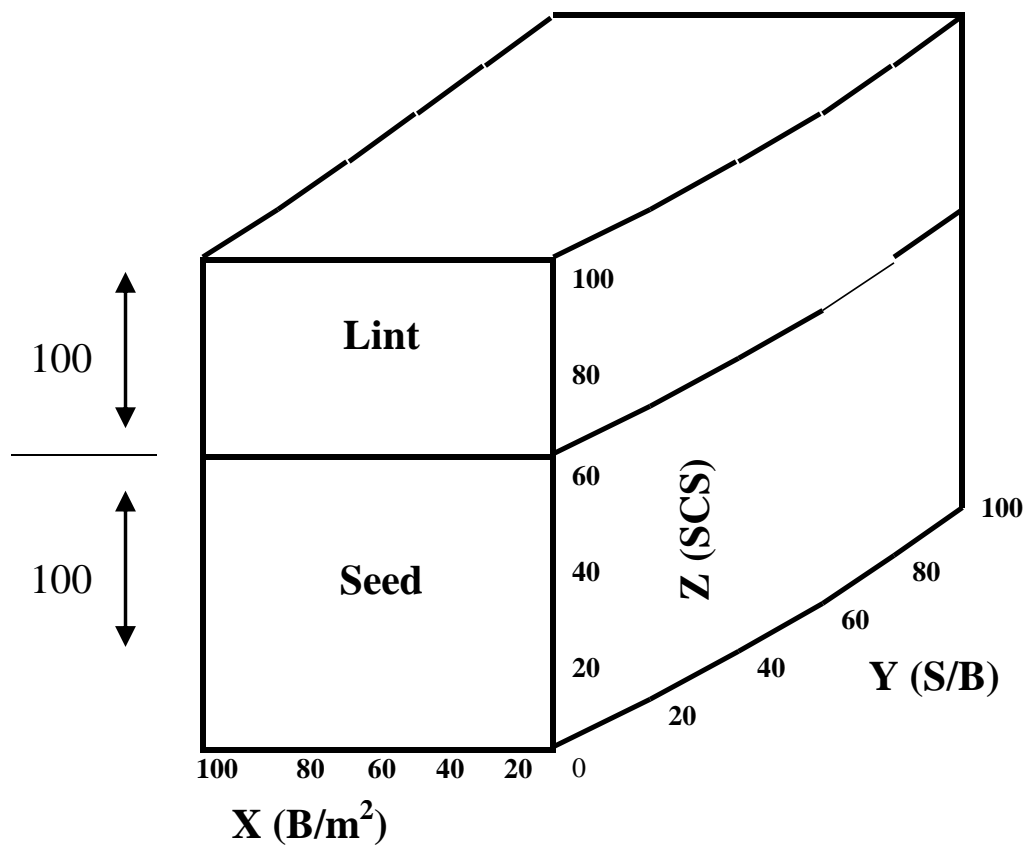

Fig 1. Yield model for Giza90 extracted from (Five locations experiment means expressed as percentage of Giza90).

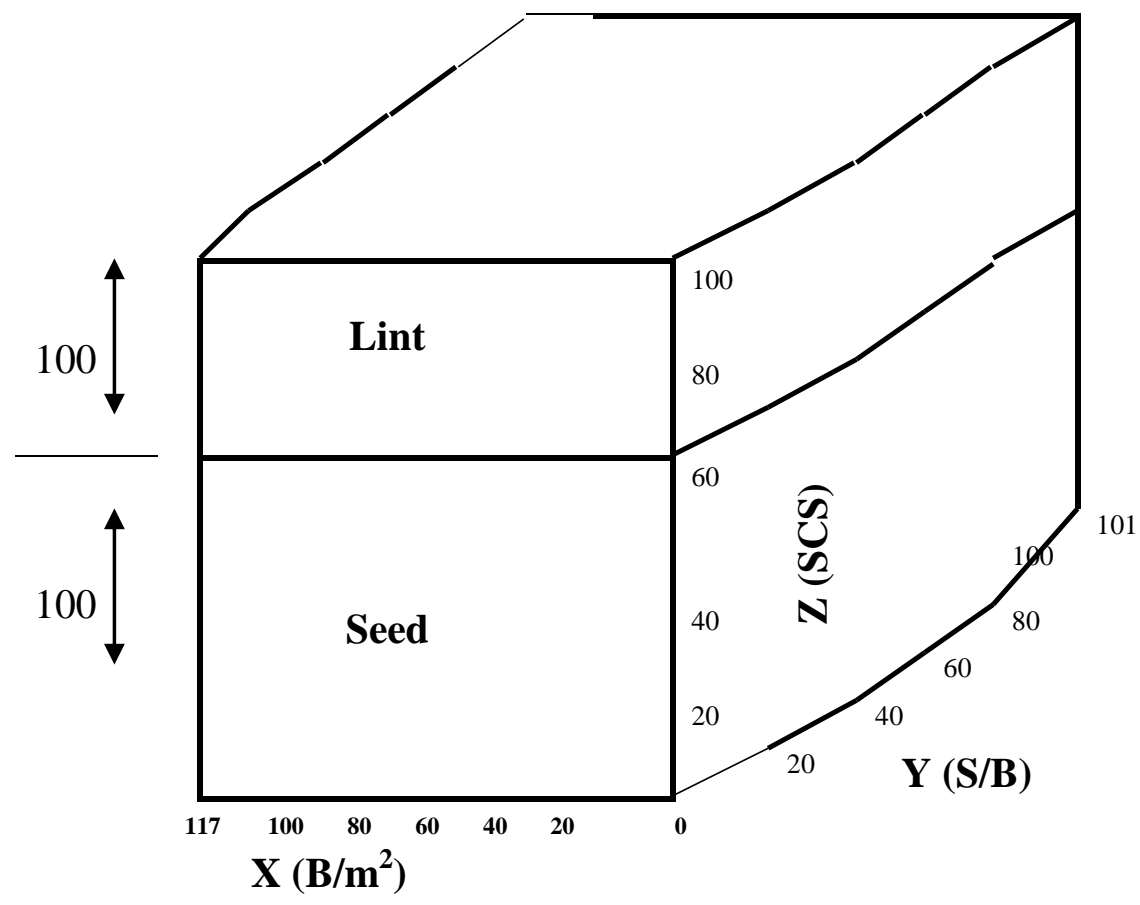

Fig 2. Yield model for H5 104/2005 [(G83x (G72xDan) xG91] extracted from (Five locations experiment means expressed as percentage of Giza90). 


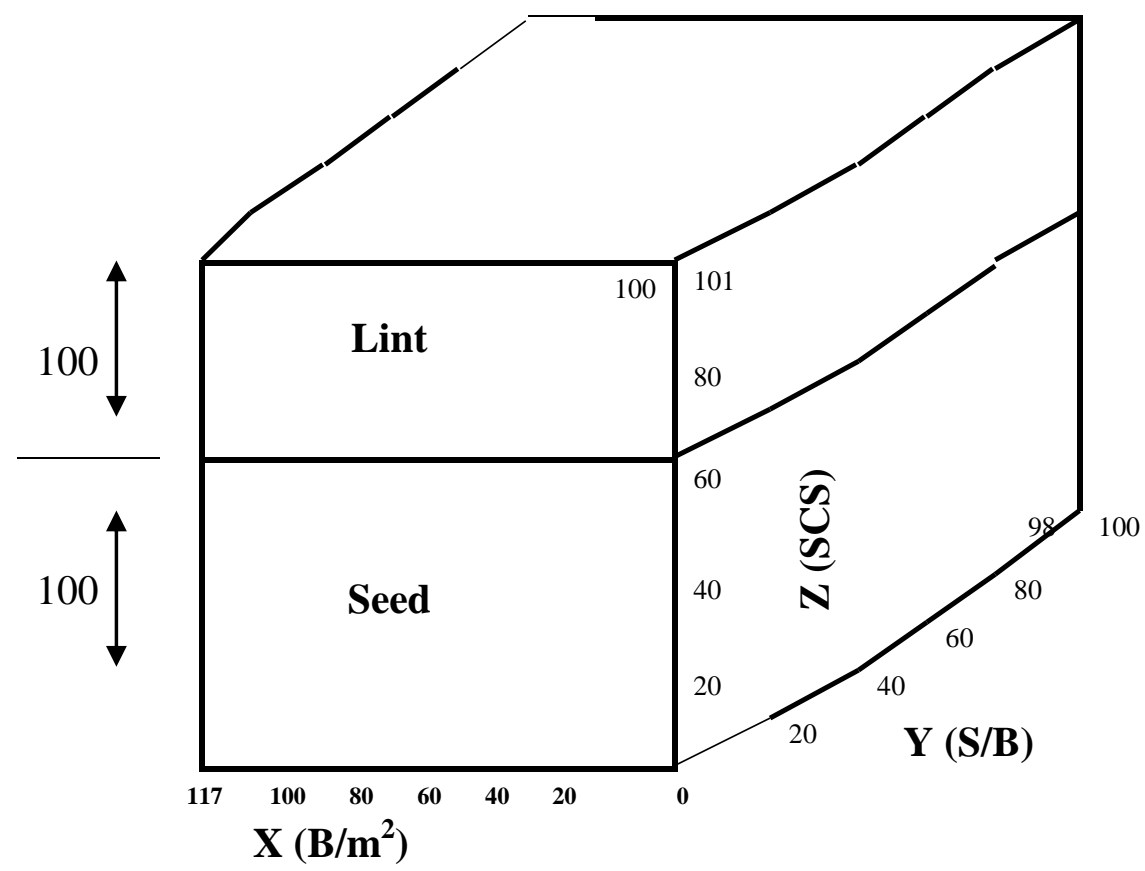

Fig 3. Yield model for $\mathrm{H}_{5}$ 124/2005 [(G83x (G72xDan) xG85 extracted from (Five locations experiment means expressed as percentage of Giza90

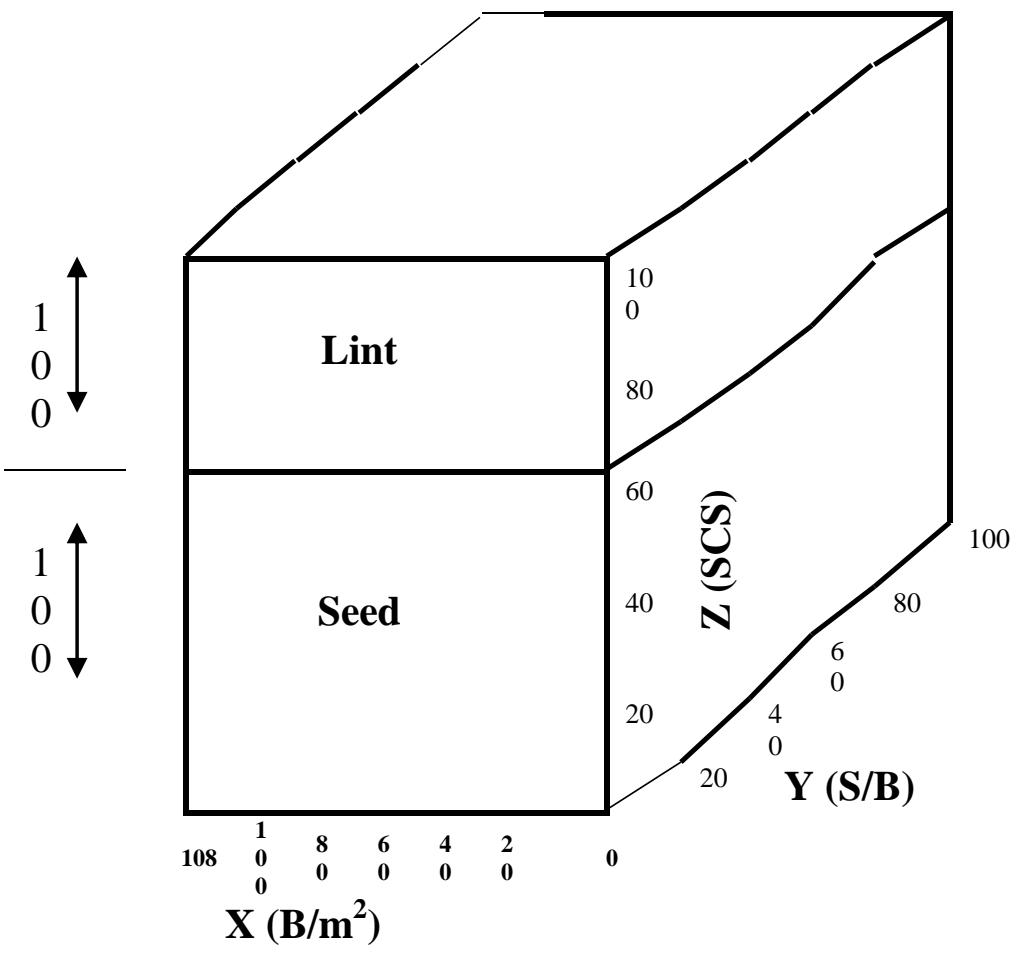

Fig 4. Yield model for $\mathrm{H}_{5}$ 141/2005 [(G83xG80) xG75] x (G83xPima S6) extracted from (Five locations experiment means expressed as percentage of Giza90). 


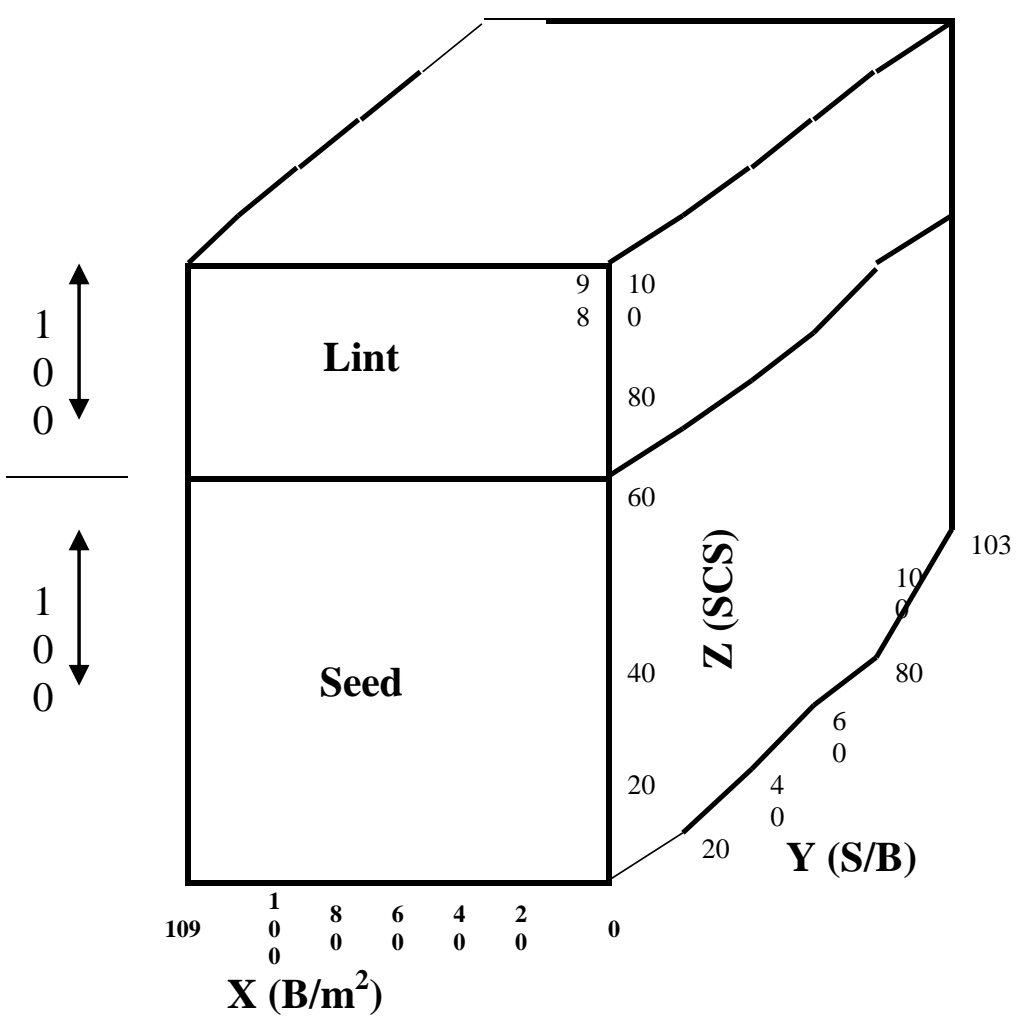

Fig 5. Yield model for $\mathrm{H}_{6}$ 161/2005 [G83x(G75x5844)] x [G83x(G72xDan)] extracted from (Five locations experiment means expressed as percentage of Giza90).

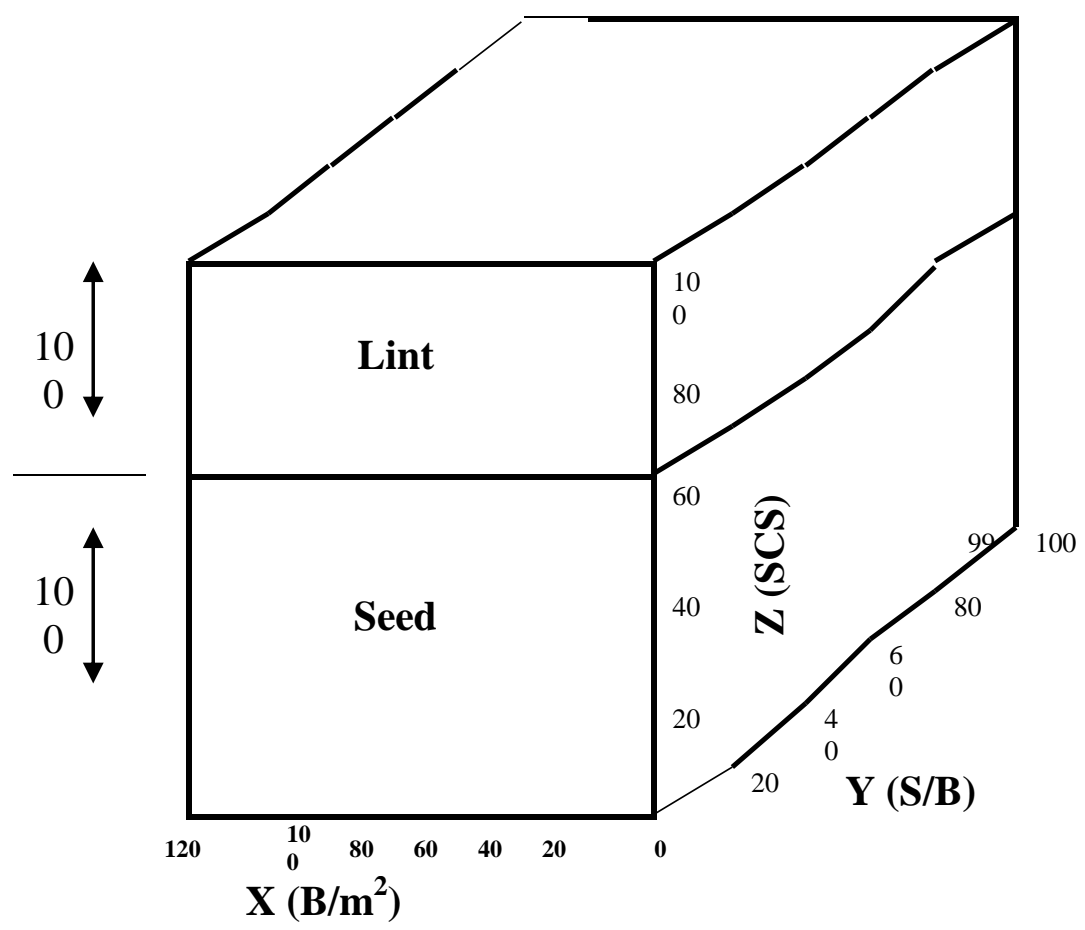

Fig 6. Yield model for $\mathrm{H}_{6}$ 162/2005 [G83x(G75x5844)] x [G83x(G72xDan)] extracted from (Five locations experiment means expressed as percentage of Giza90). 


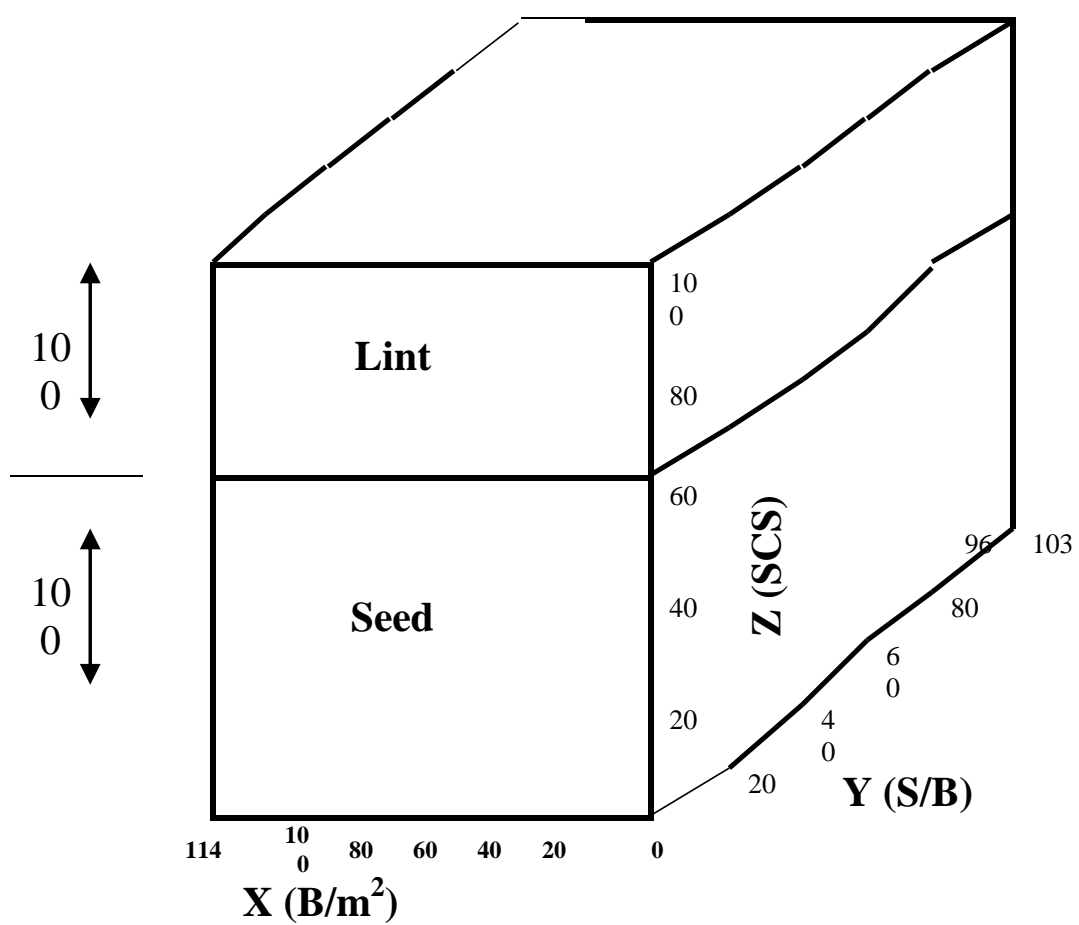

Fig 7. Yield model for H6 166/2005 [G83x(G75x5844)] x [G83x(G72xDan)] extracted from (Five locations experiment means expressed as percentage of Giza90

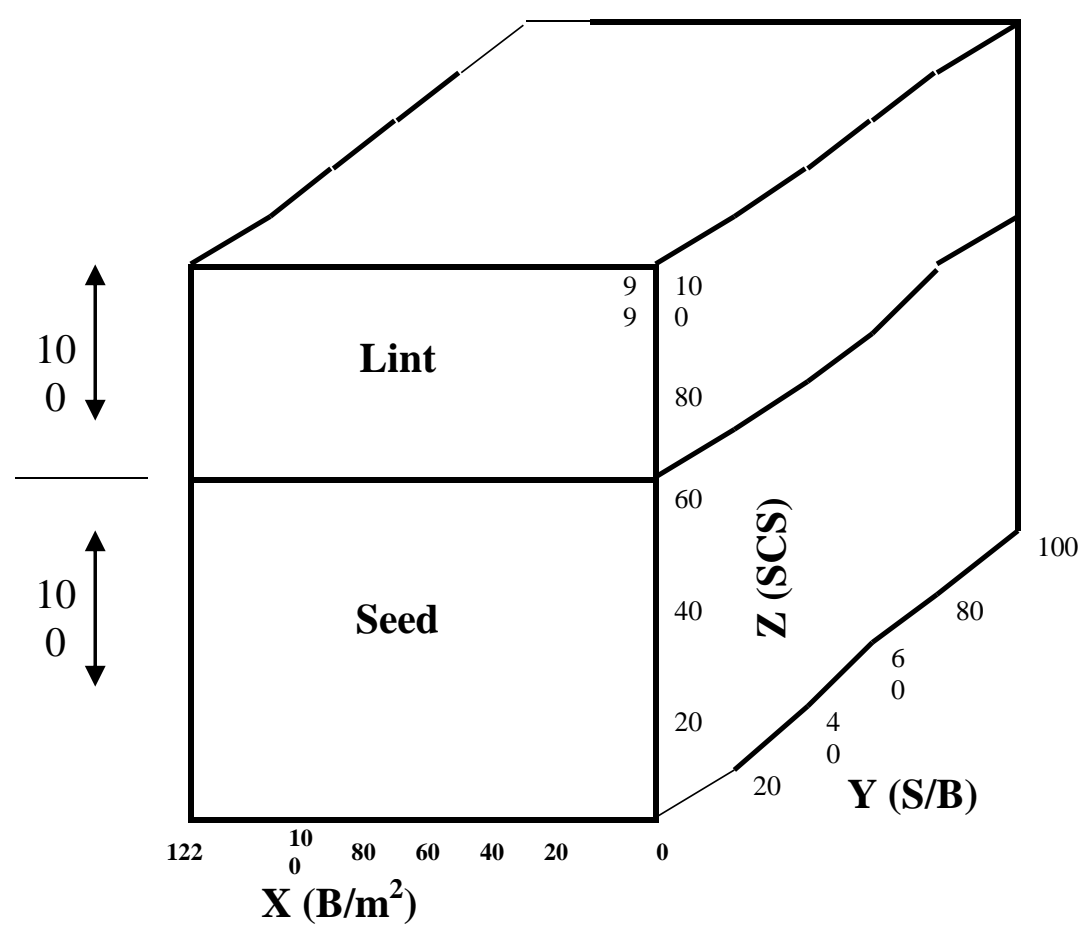

Fig 8. Yield model for H6 173/2005 [G83x (G75x5844)] x G80 extracted from (Five locations experiment means expressed as percentage of Giza90). 


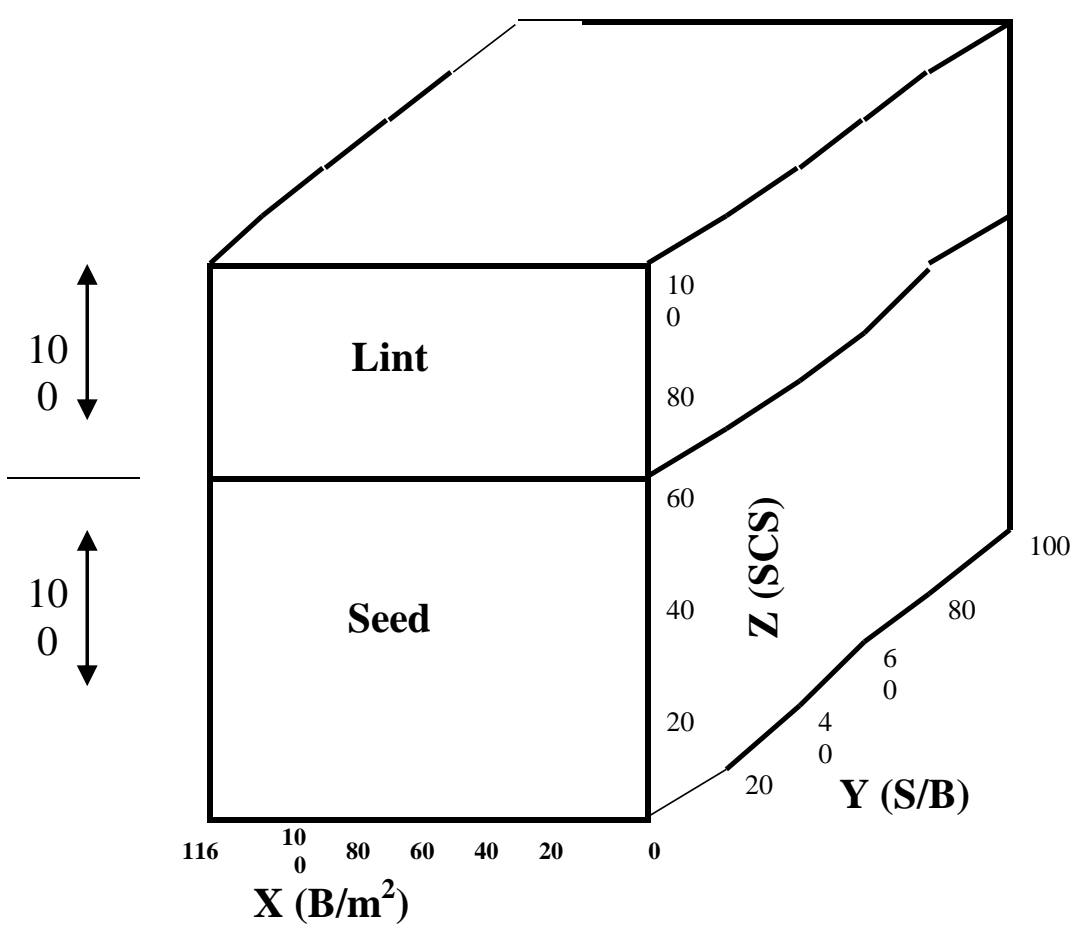

Fig 9. Yield model for H6 175/2005 [G83x(G75x5844)] x G80 extracted from (Five locations experiment means expressed as percentage of Giza90

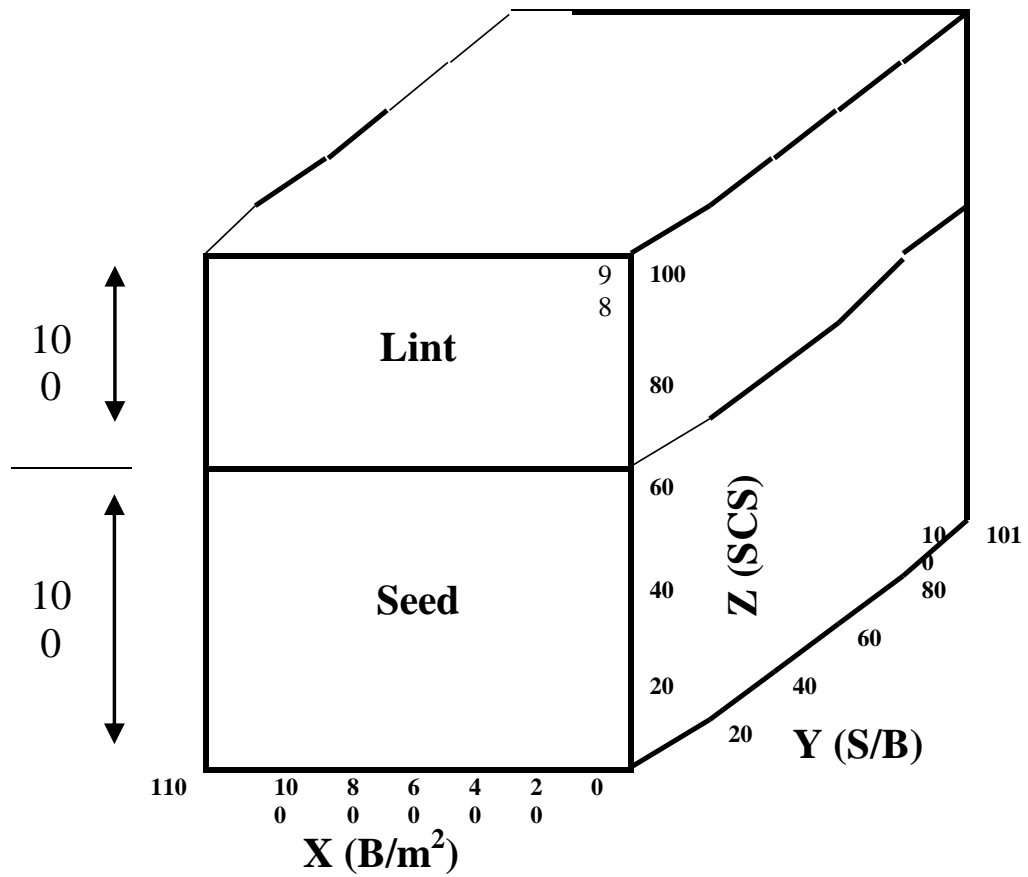

Fig 10. Yield model for H6 188/2005 (G83 x G75 x 5844) x (G80 x Pima S6) extracted from (Five locations experiment means expressed as percentage of Giza90). 


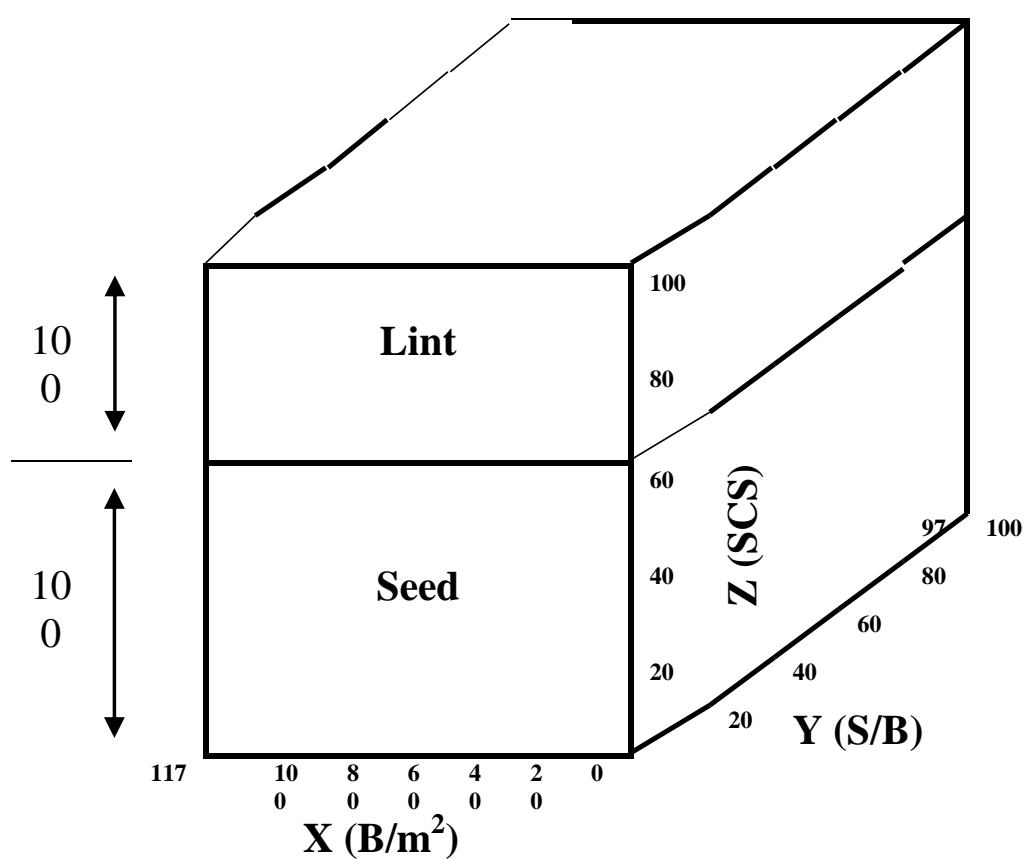

Fig 11. Yield model for H7 213/2005 (G90 x Australian) extracted from (Five locations experiment means expressed as percentage of Giza90).

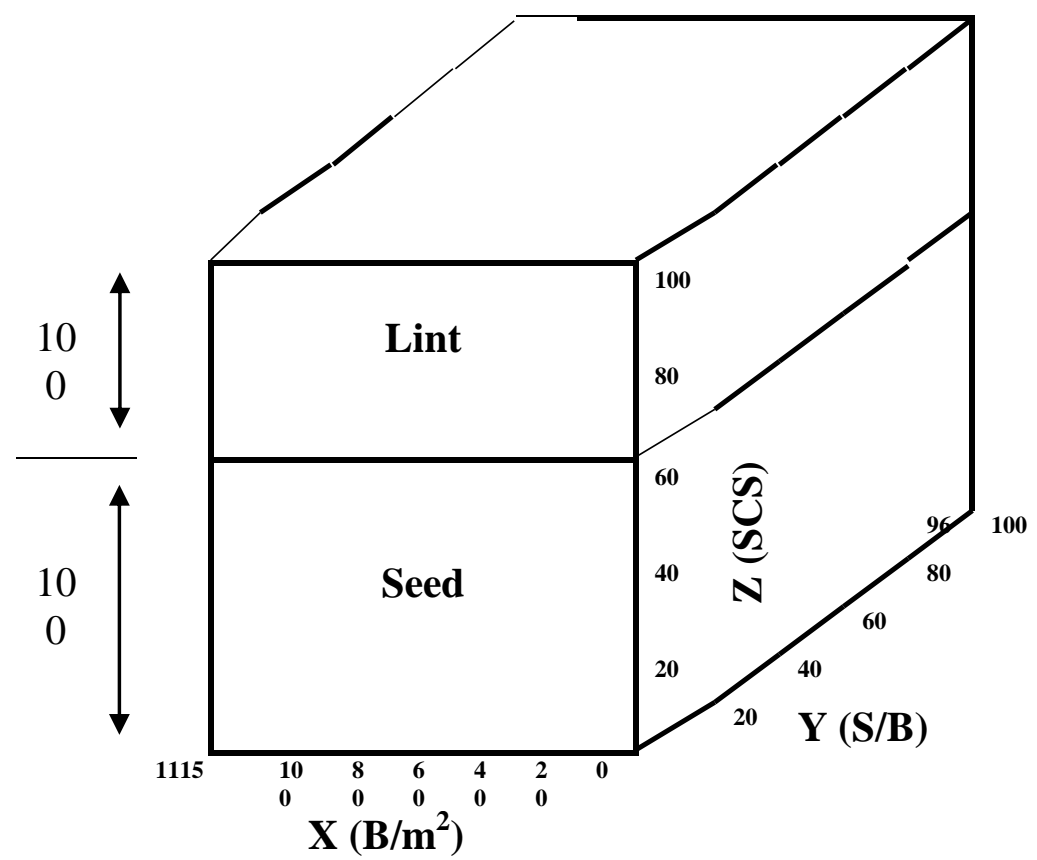

Fig 12. Yield model for H7 221/2005 G83 Radiator x G90) extracted from (Five locations experiment means expressed as percentage of Giza90). 


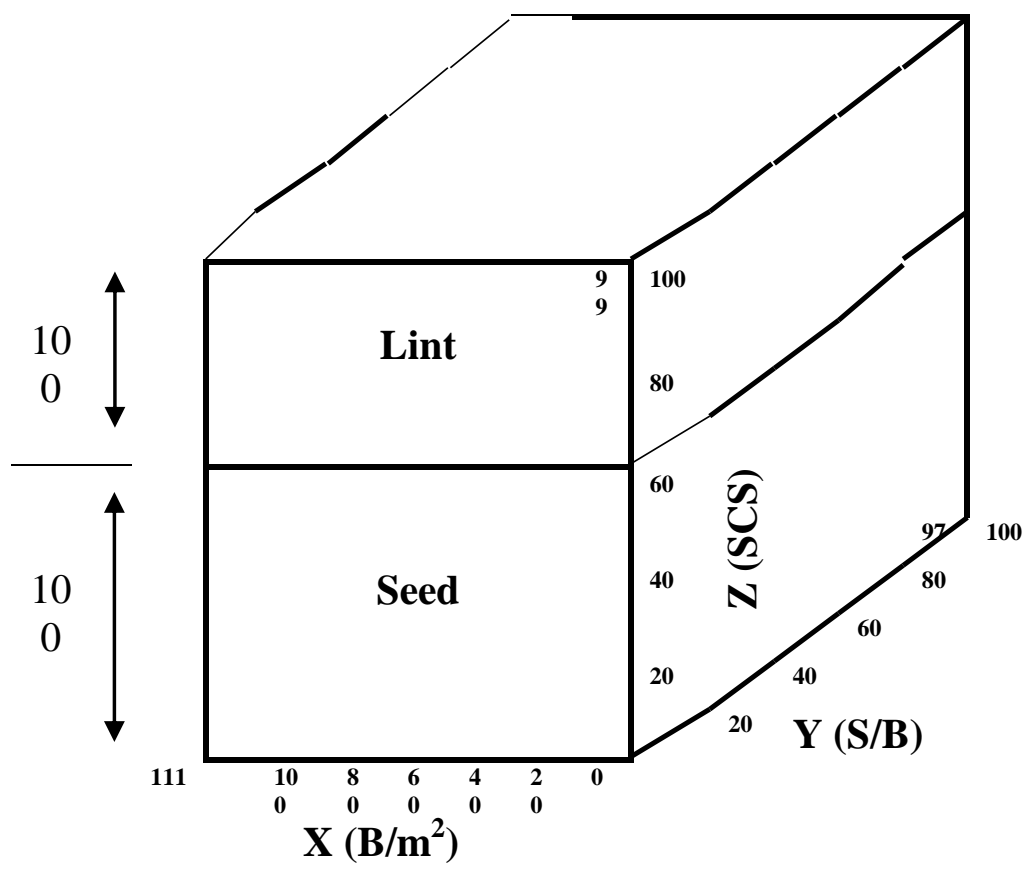

Fig 13. Yield model for H7 226/2005 (G91xG90) extracted from (Five locations experiment means expressed as percentage of Giza90).

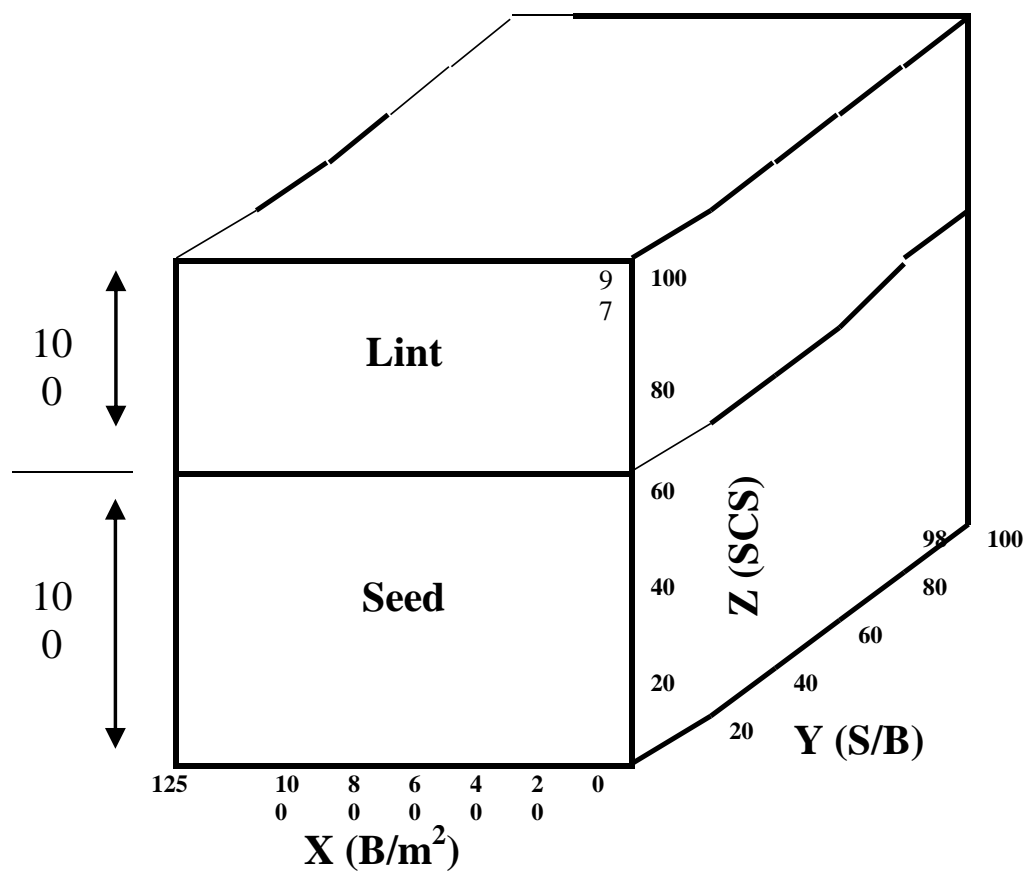

Fig 14. Yield model for H6 227/2005 (G91 x G90) extracted from (Five locations experiment means expressed as percentage of Giza90). 


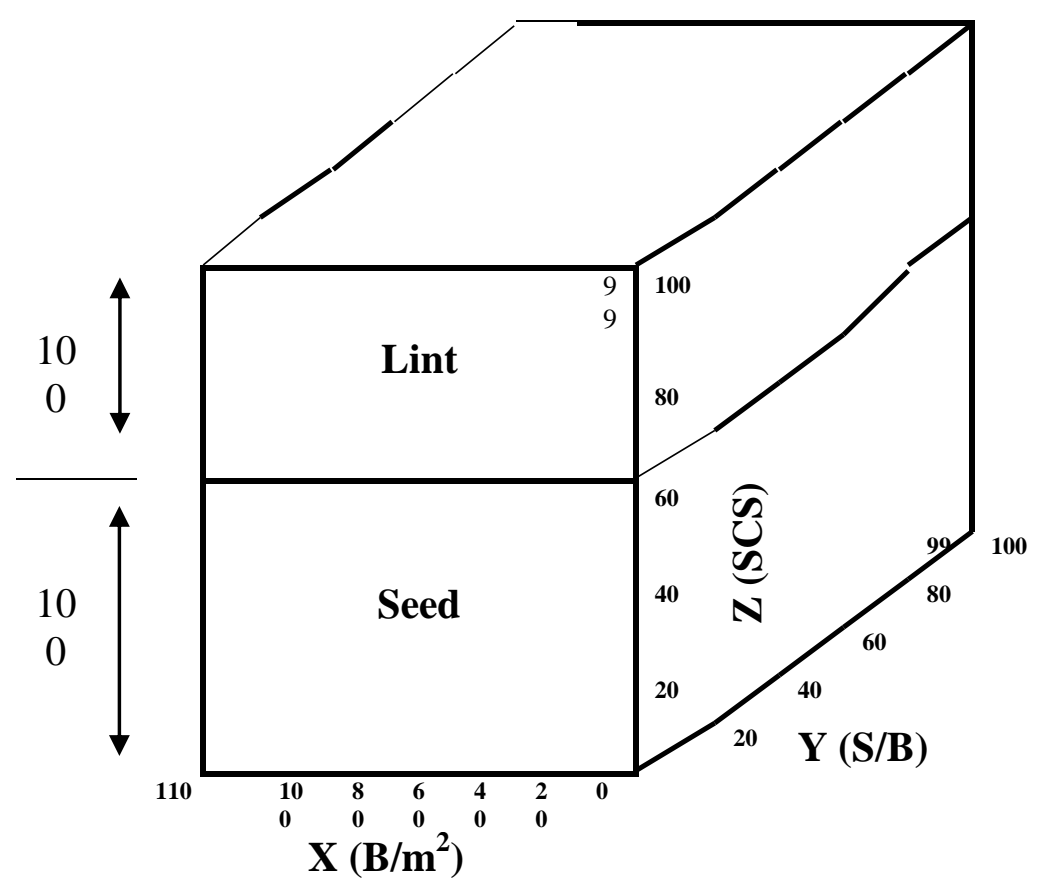

Fig 15. Yield model for H7 213/2005 (G83 x Pima S7)) extracted from (Five locations experiment means expressed as percentage of Giza90).

\section{REFERENCES}

1- Abou-Zahra, S.I.S, M.M. Awaad and Foraisa A. Al-Enani. 1993. Geometrical model of cotton yield and its components of some genotypes through a breeding programme in Middle and Upper Egypt. Zagazig J. Agric. Res. Vol.20 No.(2A)1993: 551-558.

2- Atta, Y.M., S.A. El-Shaarawy, M.A.A. Raafat and M.R.A. Rahoumah. 1989. Geometrical model for yield and yield components of some genotypes through a breeding programme for Egyptian cotton. Annals of Agric. Sci., Moshtohor, 22: 169-178, Egypt.

3- Kerr, T. 1966. Yield components in cotton and their interrelationships with fiber quality. Proc. $18^{\text {th }}$ Cotton Improvement Conf., P. 276-287.

4- Maner,B.A., L.S. Worly, D.V. Harrell and T.W. Culp. 1971. Ageometrical approach to yield models in upland cotton (G.hirsutum L.). Crop Sci., 11: 904-906.

5- Snedecor, G.W. and W.G. Cochran. 1967. Statistical methods. $7^{\text {th }}$ Edition, Iowa State Univ. Press, Ames, Towa, U.S.A. PP.325-330.

6- Shafshak, S.E., A.A. Sallam, M.K. Khalifa and M. M. Awaad. 1987. The relative contribution of yield components to lint yield of some cotton varieties. Agric. Res. Rev., 65: 589-613. 


\section{النموذج الهندسى لمحصول القطن ومكوناته لبعض التراكيب الوراثية (نوع الباريادينس)}

حسن حسين محمد العدلى ، أنور عيسى مسعود عيسى ، حسين صلاح خليفه

$$
\text { معهز بحوث القطن - مركز البحوث الزراعية - جيزة }
$$

تم دراسة النموذج الهندسى لمحصول القطن ومكوناته وذللك لعدد سبعة تراكيب وراثية والتى دونى

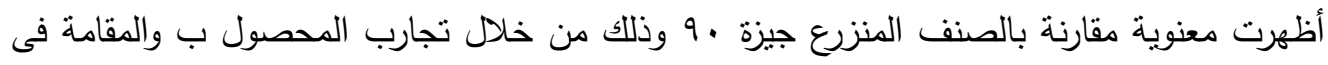

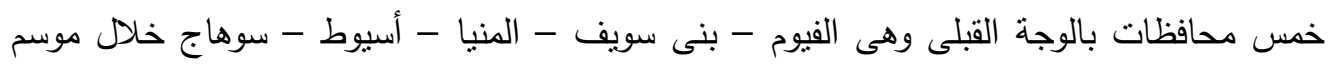

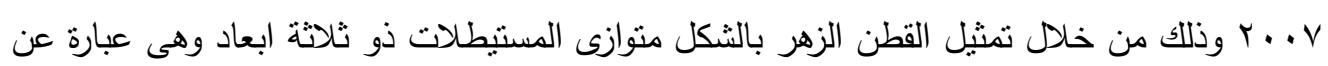

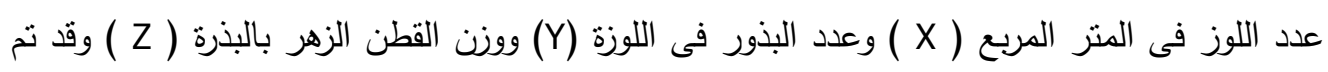

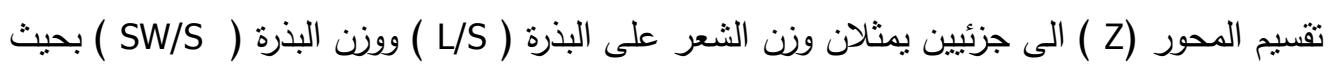
يصبح محصول القطن الثعر مساوى لحجم منوازى المسنطيلات (XYL) ).

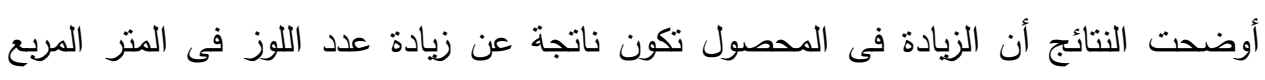
وبالتالى يمكن أن يقوم المربى بالأنتخاب لهذه الصفه مما نساعده على زيادة محصول القطن.

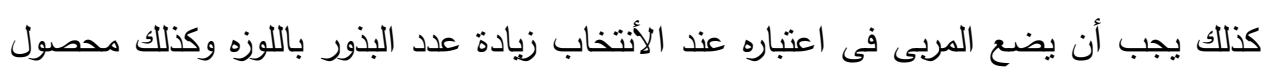

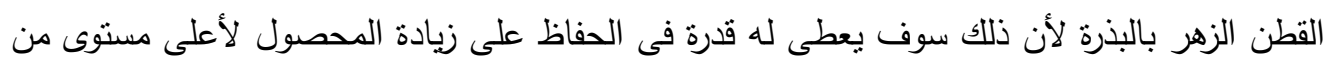

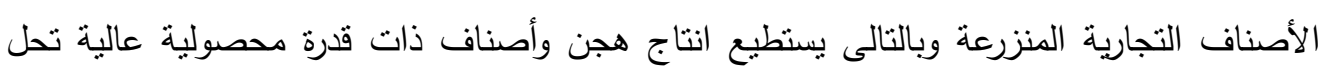

$$
\text { محل الاصناف المنزرعة. }
$$

